УДК:633.11:579.841.2

https://doi.org/10.53040/gppb7.2021.78

\title{
ВЛИЯНИЕ БАКТЕРИЙ РОДА АZОТОВАСТЕR СНRООСОССUМ НА РОСТ И РАЗВИТИЕ ПШЕНИЦЫ ОЗИМОЙ В ЗАПАДНОУКРАИНСКОЙ ЛЕСОСТЕПНОЙ ПРОВИНЦИИ
}

\author{
Кордулян Роман \\ Украинская научно-исследовательская станциия карантина растений Института защитьы расте- \\ ний НААН, Черновиьь, Украина, е-таil: kordulyanroman@gmail.com
}

\begin{abstract}
The researches results showed the positive the bacterium species Azotobacter chroococcum impact on winter wheat yield structure. Especially, the grain yield of Favoritka increased on 0,38 t/ha, or on $10 \%$; weight 1000 grains - on $2.9 \mathrm{~g}$, or on 7,5\%; the spike's length-on $0,7 \mathrm{~cm}$ or on на 9,9\%; the grain's quantity in one spike is on $2,3 \mathrm{pcs}$, or on $9 \%$; one plant's weight-on $0,23 \mathrm{~g}$, or on $5,6 \%$; the spike's weight- $0,17 \mathrm{~g}$, or on $11 \%$, one spike's grain weight- on $0,4 \mathrm{~g}$, or on $5,3 \%$.
\end{abstract}

Key words: bacterium, soil nitrogen mixer, winter wheat.

\section{Введение}

Повышение урожайности сельскохозяйственных культур в значительной степени зависит от обеспечения их элементами минерального питания, и в первую очередь азотными соединениями. Источником экологически чистого биологического азота в почве являются микроорганизмы, которые способны фиксировать молекулярный азот атмосферы $[11,12]$. Использование в практике земледелия биологических препаратов, созданных на основе азотфиксирующих микроорганизмов, является одним из технологических приемов повышения урожайности культурных растений $[1,6,7,9,10,13]$.

Почвенные микроорганизмы, принадлежащие к роду Azotobacter, характеризуются рядом положительных эффектов, среди которых определяющими являются способность к фиксации молекулярного азота, синтез соединений гормональной природы, витаминов, антибиотических веществ $[1-5,8]$. Итак, перспективным является исследование возможности использования этих бактерий в практике растениеводства и биологического земледелия.

Целью исследований было изучение влияния бактерий рода Azotobacter chroococcum на рост и развитие кукурузы в Западноукраинской лесостепной провинции.

\section{Материалы и методы}

Для исследований использованы бактериальный препарат, действующим веществом которого были бактерии рода Azotobacter chroococcum. Определение урожайности, ее структуры и других показателей на пшенице озимой определяли методом учетных участков.

Эффективность применения препарата изучали в условиях полевого опыта УкрНИСКР ИЗР HAAH.

Схема опыта представляла собой четыре участка по 0,25 га на которых применялся препарат и контрольный участок (без обработок) площадью 0,25 га. Общая площадь опытного участка - 1,25 га.

Исследуемые сорта: пшеница озимая - Фаворитка.

Норма расхода: обработка семян озимой пшеницы - 2 л/т. Нормы расхода рабочего раствора: 10 л/гектарную норму.

Опытный участок находится на черноземе оподзоленном с низким содержанием гумуса $(2,1 \%)$ и слабокислой реакцией почвенного раствора (pH - 4,8-5,0). Обеспеченность почвы фосфором очень низкая (Р2О5 - 45 мг / кг), калием - низкая (К2О - 66 мг / кг), лужногидролизованым азотом - очень низкая (76 мг / кг), агрохимическая оценка в баллах - 28 из 100.

Агротехнические мероприятия, которые проводили на опытном участке: применение севооборота и правильное чередование культур в ней, система обработки почвы, система удобрения, подготовка семенного и посадочного материала, правильные сроки и способы посева, посадки растений и сбора урожая. 
Защиту от болезней, вредителей и сорняков на вариантах опыта проводили согласно технологическим картам выращивания пшеницы озимой (достаточный уровень ресурсного обеспечения).

Метеорологические условия: средняя дата начала вегетационного периода в 2017-2020 гг. на территории, где проведены исследования, была 20 марта, окончание - 21 октября. Гидротермический коэффициент составлял 1,2 .

Приведены в табл. 1 метеорологические показатели указывают на увеличение количества осадков в весенний период с марта по май и в июле, и существенное уменьшение их количества в июне и августе-октябре. Температурный режим почти во все месяцы превышал средний многолетний показатель на $1,1-2,6{ }^{\circ} \mathrm{C}$, за исключением марта, где разница составила $+4,5{ }^{\circ} \mathrm{C}$. Такие условия должны были иметь достаточное влияние на рост и развитие исследуемых культур.

Таблица 1. Метеорологические условия в период проведения исследований (МСЦ Черновцы), 2017-2020 гг.

\begin{tabular}{|c|c|c|c|c|}
\hline \multirow[t]{3}{*}{ Месяц } & \multicolumn{4}{|c|}{ Показатели } \\
\hline & \multicolumn{2}{|c|}{ Количество осадков, мм } & \multicolumn{2}{|c|}{$\begin{array}{c}\text { Среднемесячная температура } \\
\text { воздуха, }{ }^{\circ} \mathrm{C}\end{array}$} \\
\hline & $\begin{array}{c}\text { За опыт- } \\
\text { ный пери- } \\
\text { од }\end{array}$ & $\begin{array}{c}\text { Среднемесячная } \\
\text { многолетняя нор- } \\
\text { ма }\end{array}$ & $\begin{array}{c}\text { За опытный } \\
\text { период }\end{array}$ & $\begin{array}{c}\text { Многолетняя } \\
\text { норма }\end{array}$ \\
\hline Март & 34 & 32 & 7,2 & 2,7 \\
\hline Апрель & 44 & 47 & 10,3 & 9,2 \\
\hline Май & 102 & 76 & 15,2 & 14,9 \\
\hline Июнь & 32 & 88 & 17,8 & 18,0 \\
\hline Июль & 103 & 98 & 20,3 & 19,8 \\
\hline Август & 51 & 77 & 20,2 & 19,1 \\
\hline Сентябрь & 9 & 49 & 15,7 & 14,3 \\
\hline Октябрь & 19 & 37 & 11,4 & 8,8 \\
\hline $\begin{array}{c}\text { Сумма осадков за вегетационный } \\
\text { период }\end{array}$ & 394 & 504 & & \\
\hline Средняя tº за вегетационный период & & & 14,8 & 13,4 \\
\hline
\end{tabular}

\section{Результаты и обсуждение}

В 2017-2020 гг. использование препарата, действующим веществом которого были бактерии рода Azotobacter chroococcum, для предпосевной обработки семян и опрыскивания почвы положительно влияло на основные качественные показатели пшеницы озимой.

Препарат способствовал повышению густоты стеблестоя пшеницы озимой сорта Фаворитка в фазе кущения в среднем на 107 растений/м2 по сравнению с контролем, или на 18,1\%. Предпосевная обработка семян препаратом существенно влияла на варьирование основных биометрических показателей. Так, высота растений в фазе кущения на вариантах по сравнению с контрольными участками в посевах сорта Фаворитка выросла на 11,7 см, или на 12,8\%.

Таблица 2.Влияние бактерий рода Azotobacter chroococcum на структуру урожая озимой пшеницы (сорт Фаворитка), УкрНИСКР ИЗР НААН, 2017-2020 гг.

\begin{tabular}{|c|c|c|c|c|c|c|c|c|c|}
\hline $\begin{array}{c}\text { Норма расхода препа- } \\
\text { рата }\end{array}$ & $\begin{array}{l}\text { Урожай- } \\
\text { ность, т/ге }\end{array}$ & $\begin{array}{c}\text { Густота } \\
\text { стебло-стоя } \\
\text { шт./M² }\end{array}$ & $\begin{array}{c}\text { Высота } \\
\text { растения, см }\end{array}$ & $\begin{array}{c}\text { Длина } \\
\text { колоса, } \\
\text { см }\end{array}$ & \begin{tabular}{|c|} 
Количе- \\
ство зере \\
в колосе, \\
шт. \\
\end{tabular} & $\begin{array}{c}\text { Масса одно } \\
\text { ro растения } \\
\Gamma\end{array}$ & $\begin{array}{l}\text { Масса } \\
\text { колоса, }\end{array}$ & $\begin{array}{c}\text { Масса } \\
\text { зерна, } \\
\Gamma\end{array}$ & $\begin{array}{c}\text { Масса } \\
1000 \\
\text { зерен, Г }\end{array}$ \\
\hline Без обработок & 3,41 & 484 & 79,4 & 6,4 & 23,3 & 3,85 & 1,38 & 0,72 & 35,5 \\
\hline $\begin{array}{l}\text { Предпосевная обработ- } \\
\text { ка семян пшеницы яро- } \\
\text { вой } 500 \text { мл/одну гек- } \\
\text { тарную норму (рабоче- } \\
\text { го раствора: } 10 \text { л/т) }\end{array}$ & 3,79 & 591 & 91,1 & 7,1 & 25,6 & 4,08 & 1,55 & 0,76 & 38,4 \\
\hline $\mathrm{HIP}_{05}$ & 0,26 & 13,86 & 2,01 & 0,39 & 1,94 & 0,11 & 0,09 & 0,01 & 2,11 \\
\hline
\end{tabular}


Анализ морфометрических показателей свидетельствует, что общая эффективность исследуемого препарата во всех случаях существенно увеличилась. Урожайность зерна сорта Фаворитка увеличилась на 0,38 т / га, или на 10\%, масса 1000 зерен - на 2,9 ч, или на 7,5 \%, длина колоса на 0,7 см, или на 9,9\%, количество зерен в одном колосе - на 2,3 шт., или на $9 \%$, масса одного растения - на 0,23 г, или на 5,6\%, масса колоса - на 0,17 г, или $11 \%$; масса зерна с колоса - на 0,4 ч, или на 5,3 \% (табл. 2).

\section{Выводы}

При применении бактерий рода Azotobacter chroococcum для обработки семян зерновых культур (пшеница озимая), наблюдали существенный рост большинства качественных показателей растений и урожая.

\section{Литература}

1. Біологічний азот / Патика В. П. та ін. Київ : Світ, 2003. 424 с.

2. Гормоны и гормоноподобные соединения микроорганизмов / Цавкелова Е. А. и др. Прикладная биохимия и микробиология. 2006. № 3. С. 261-268.

3. КИРИЧЕНКО, Е. В., КОЦЬ, С. Я. Использование Azotobacter chroococсит для создания комплексных биологических биопрепаратов. Biotechnologia Acta. 2011. № 3. С. 74-81.

4. КИРИЧЕНКО, Е. В., ТИТОВА, Л. В., КОЦЬ, С. Я. Эффективность бактеризации семян пшеницы яровой новым штаммом Azotobacter chroococcum T79. Агр. наука. 2010. № 1. С. 21-24.

5. Мікробні біотехнології в сільському господарстві / Смірнов В. В. та ін. Агроекологічний журнал. 2002. № 3. C. 3-9.

6. Мікробні препарати у землеробстві: теорія і практика / Волкогон В. В. та ін. Київ : Аграрна наука, 2006. $312 \mathrm{c}$.

7. Микроорганизмы - продуценты стимуляторов роста растений и их практическое применение / Цавкелова Е. А. и др. Прикладная биохимия и микробиология. 2006. № 2. С. 133-143.

8. МОРГУН, В. В., КОЦЬ, С. Я., КИРИЧЕНКО, О. В. Ростстимулирующие ризобактерии и их практическое применение. Физиология и биохимия культурных растений. 2009. № 3. С. 187-207.

9. ПАТИКА, В. П. Стан і перспективи досліджень мікробної азотфіксації. Онтогенез рослин, біологічна фіксаиія молекулярного азоту та азотний метаболізм. Тернопіль, 2001. С. 111-115.

10. ТИХОНОВИЧ, И. А., КРУГЛОВ, Ю. В. Биопрепараты в сельском хозяйстве (методология и практика использования микроорганизмов в растениеводстве и кормопроизводстве). Москва : Россельхозакадемия, 2005. $154 \mathrm{c.}$

11. УМАРОВ, М. М. Азотфиксация в биосфере и биотехнологический потенциал диазотрофов. Бюл. Моск о-ва испыт. природы, отд. биол. 2007. 112. Прил. 1. С. 150-155.

12. ЧЕРЕМИСОВ, Б. М. О быстром переходе мирового земледелия на биологическую фиксацию азота атмосферы (концепция БАРС). Вест. Рос. акад. с.-х. наук. 2006. № 2. С. 39-41.

13. ALTAF, M. M., AHMAD, I. In vitro and in vivo biofilm formation by Azotobacter isolates and its relevance to rhizospere colonization. Rhizosphere. 2017. Vol. 3. P. 138-142. 